\title{
ENDOPLASMIC RETICULUM INVOLVEMENT IN DRUG-INDUCED GINGIVAL OVERGROWTH
}

\author{
ANCUTA GORIUC ${ }^{1 \sharp}$, IONUT LUCHIAN ${ }^{2 *}$, ALEXANDRA JITAREANU ${ }^{3 *}$, LILIANA FOIA $^{1}$, \\ MARIA BOGDAN $^{4}$, DANA BUDALA ${ }^{5}$, DIANA TATARCIUC ${ }^{6}$, IOANA MARTU $^{7}$
}

\author{
${ }^{1}$ Department of Biochemistry, Faculty of Medicine, "Grigore T. Popa” University of Medicine and Pharmacy, 700115, Iași, \\ Romania \\ ${ }^{2}$ Department of Periodontology, Faculty of Dental Medicine, "Grigore T. Popa" University of Medicine and Pharmacy, \\ 700115, Iași, Romania \\ ${ }^{3}$ Department of Toxicology, Faculty of Pharmacy, “Grigore T. Popa” University of Medicine and Pharmacy, 700115, Iași, \\ Romania \\ ${ }^{4}$ Department of Pharmacology, University of Medicine and Pharmacy, Craiova, Romania \\ ${ }^{5}$ Department of Proshodontics, Faculty of Dental Medicine, "Grigore T. Popa" University of Medicine and Pharmacy, \\ 700115, Iași, Romania \\ ${ }^{6}$ Department of Internal Medicine, Faculty of Medicine, "Grigore T. Popa” University of Medicine and Pharmacy, 700115, \\ Iași, Romania \\ ${ }^{7}$ Department of Dental Technology, Faculty of Dental Medicine, "Grigore T. Popa” University of Medicine and Pharmacy, \\ 700115, Iaşi, Romania
}

*corresponding author: ionut.luchian@umfiasi.com

\#Authors with equal contribution.

Manuscript received: January 2021

\begin{abstract}
Gingival overgrowth is an undesirable and well-recognized side effect following the use of various drugs, such as phenytoin, nifedipine and cyclosporine A (CsA). Apoptosis constitutes a necessary process for constant tissue remodelling, its absence playing a critical role in gingival overgrowth. The aim of this study was to evaluate the effects of THP (thapsigargin), brefeldin A, cyclopiazonic acid, and capsaicin on the endoplasmic reticulum (ER) and their involvement in apoptosis of normal fibroblasts compared with those treated with drugs. These substances are well known for inducing stress in the ER through different mechanisms, thus leading to the induction of apoptosis. In conclusion, ER stress induction in normal fibroblasts using cyclopiazonic acid, THP, brefeldin A and capsaicin had no significant effects on mitochondrial permeability transition pore opening. In the case of CsA or nifedipine pre-treatment, cyclopiazonic acid, capsaicin and THP decreased mitochondrial calcein, suggesting that the opening of mitochondrial permeability transition pore (MPTP) is due to ER stress. For the phenytoin pre-treatment case, only cyclopiazonic acid, and capsaicin have induced significant effects on MPTP.
\end{abstract}

\section{Rezumat}

Hipercreșterea gingivală reprezintă un efect secundar ce apare la administrarea mai multor substanțe medicamentoase, precum fenitoină, nifedipină și ciclosporină. Apoptoza constituie un proces indispensabil pentru remodelarea tisulară continuă, iar absența acesteia joacă un rol important în hipercreșterea gingivală. Scopul prezentului studiu a fost evaluarea efectelor thapsigargin (THP), brefeldin A, acidului ciclopiazonic şi a capsaicinei asupra reticulului endoplasmic (RE) şi implicarea în apoptoza fibroblastelor tratate cu substanțele menționate. În concluzie, inducerea stresului la nivelul RE în culturile de fibroblaste normale tratate cu THP, brefeldin A, acid ciclopiazonic și capsaicină nu a influențat semnificativ deschiderea porului de permeabilitate tranzitorie mitocondrială (MPTP). În cazul tratamentului prealabil cu ciclosporină A sau cu nifedipină, acidul ciclopiazonic, capsaicina și THP au determinat scăderea încărcării mitocondriale cu calceină, sugerând că deschiderea MPTP se datorează stresului RE. În cazul pre-tratamentului cu fenitoină, doar acidul ciclopiazonic și capsaicina au indus modificări semnificative asupra MPTP.

Keywords: endoplasmic reticulum stress, apoptosis, drug-induced gingival overgrowth

\section{Introduction}

Drug-induced gingival overgrowth or enlargement manifests as an abnormal growth of the gingiva because of adverse drug reactions (ADR) in patients treated with anticonvulsants, immunosuppressants, and calcium channel blockers [1-3].
Currently, the aetiology of drug-induced gingival overgrowth is not entirely understood, although it is clearly multifactorial $[4,5]$. Gingival overgrowth represents a side effect for three categories of drugs that seem to have multifactorial pathogenesis with a common 
molecular action: the blockage of the cell membrane in the $\mathrm{Ca}^{2+/} \mathrm{Na}^{+}$ion flow [6].

There are several hypothetical mechanisms for cyclosporine A - induced gingival overgrowth, such as genetic predisposition, altered homeostasis of gingival tissues, especially fibroblast function, changes in the cytokines balance and in collagen degradation [7].

Previous studies have shown that the administration of different drugs, such as nifedipine and phenytoin stimulates a number of growth factors such as bFGF (basic fibroblasts growth factor), TGF- $\beta$ (transforming growth factor beta), HSPG (heparin sulphate glycosaminoglycan) [8].

The change of balance between cell proliferation and apoptosis was previously mentioned as one of the mechanisms for drug induced gingival overgrowth [9]. Furthermore, in vitro studies revealed that the stimulation of gingival fibroblasts with CsA for $24 \mathrm{~h}$ caused a significant decrease in the apoptosis rate through both the intrinsic and extrinsic pathways, mitochondria and ER playing an important role in this process [10].

We acknowledge that the early important events in apoptosis take place at the mitochondrial and ER level by cytochrome $\mathrm{c}$ and calcium release in the cytoplasm $[11,12]$.

The ER is the site for synthesis, folding, modification and trafficking of secretory and cell-surface proteins. As a major intracellular calcium storage compartment, the ER also plays a critical role in the maintenance of cellular calcium homeostasis [13].

The alterations in calcium homeostasis and the accumulation of misfolded proteins in ER cause ER stress and lead to programmed cell death. The mobilization of ER calcium stores can initiate the activation of cytoplasmic death pathways, as well as sensitizing mitochondria to direct proapoptotic stimuli [14].

Recent studies have shown that ER stress triggers programmed cell death through the intrinsic pathway, an alternative apoptosis in contrast to the intrinsic described above is independent of Apaf-1 and cytochrome C [15].

In order to maintain homeostasis against any ER dysfunction, the ER responds through a complex and coordinated adaptive signalling mechanism, called the unfolded protein response (UPR) [16].

Evidence proving the role of ER stress in apoptosis induction in a variety of prevalent chronic diseases, make this mechanism a tempting target for therapeutic intervention $[17,18]$. One of the strategies used in various pathologies, is to reduce the endoplasmic reticulum stress by using proteostasis regulators, such as 4-phenyl butyric acid (PBA) and tauroursodeoxycholic acid (TUDCA). Even if previous animal studies emphasized important effects in mice, the link between ER stress, apoptosis and the beneficial role of these substances in different pathologies is still unclear [19].
There is increasing evidence of ER stress triggered apoptosis in the pathogenesis or exacerbation of a widespread number of disease processes. In addition, the possibility of a molecular link between UPR various pathways or how their separate, but complementary actions may have critical roles in apoptosis, hypothesis have not been adequately addressed by most of the published studies in this area. Progress in these areas is essential to gain a more global understanding of this topic and to optimize the design of new therapeutic strategies. Given the importance of endoplasmic reticulum involvement in the prevalence of different apoptosis induced diseases, it is understandable why this subject needs more clarification and detailed studies [20].

The aim of this study was to follow the effects of thapsigargin (THP), brefeldin A, cyclopiazonic acid and capsaicin on the ER and its involvement in normal fibroblasts apoptosis compared with drug treated fibroblasts.

\section{Materials and Methods}

The present study was approved by the Ethics Committee of "Grigore T. Popa" University of Medicine and Pharmacy (Iași, Romania). All protocols were in accordance with the provisions of the Declaration of Helsinki.

The cell culture was achieved by the explant technique from male rats gum. After ether anaesthesia, rat gingival tissues were obtained from the attached gingiva of a Wistar rat. Small fragments of gingiva (approximately $2 \times 2 \mathrm{~mm}$ pieces) were maintained in culture in Petri dishes with Dulbecco culture medium supplemented with L-glutamine, glucose, 10\% FBS (foetal bovine serum), $1 \%$ antibiotics mixture penicillin/streptomycin and $1 \%$ amphotericin B. Obtaining fibroblasts using this technique required between 2 and 7 days. In order to obtain gingival fibroblasts, we used a specific growth medium for these cell types. The characteristic morphology of the fibroblasts was observed through light microscopy. We also took into account the fact that gingival fibroblasts are adherent cells and resist several passages while other cells like keratinocytes are lost after 2 - 3 passages. Viability of the cells was evaluated by trypan blue exclusion.

After the cells reached confluence, they were multiplied and afterwards, two passages were divided into four equal groups. In three of them, medium was supplemented with cyclosporine A $(\mathrm{CsA})$ treatment $(1 \mu \mathrm{M})$, nifedipine ( $3 \mathrm{mM}$ ) and phenytoin $(2.5 \mathrm{mM})$ for 7 days. The doses used have been previously shown $[21,22,23]$ to produce side effects at cellular level, such as inhibition of apoptosis and opening the MPTP. We have used a control group that received no treatment.

Using flow cytometry, we evaluated the involvement of endoplasmic reticulum in normal fibroblasts apoptosis and those treated with CsA, nifedipine and phenytoin 
using calcein AM as a marker for mitochondrial permeability transition pore opening.

The protocol consisted in normal and treated fibroblasts trypsinization with trypsin-EDTA, flushing them by centrifugation at 300x g for 5 minutes, after which their resuspension was performed in $1 \mathrm{~mL}$ Dulbecco culture medium. Cells were counted using a Neubauer chamber and were equally divided in six tubes (about $1,000,000$ cells $/ \mathrm{mL}$ in each tube) for each cell type (normal fibroblasts, treated with CsA, nifedipine and phenytoin).

A tube represented the control group. We added calceinAM $(2 \mu \mathrm{M})$ and $\mathrm{CoCl}_{2}$ (cobalt chloride) $(80 \mu \mathrm{M})$ for 20 minutes at $37^{\circ} \mathrm{C}$ and $5 \% \mathrm{CO}_{2}$ in all the other tubes. We followed mitochondrial permeability transition pore opening using calcium ionophore A23187 (10 $\mu \mathrm{M}$ Sigma-Aldrich $^{\circledR}$, Germany) for 24 hours.

As apoptosis inducer, we added thapsigargin $(10 \mu \mathrm{M}-$ Sigma-Aldrich ${ }^{\circledR}$, Germany), cyclopiazonic acid (10 $\mu \mathrm{M}$ - Sigma-Aldrich ${ }^{\circledR}$, Germany), brefeldin A (10 $\mu \mathrm{M}-$ $\left.\mathrm{AbCam}^{\circledR}, \mathrm{USA}\right)$ and capsaicin $\left(50 \mu \mathrm{M}\right.$ - Sigma-Aldrich $^{\circledR}$, Germany) for 24 hours at $37^{\circ} \mathrm{C}$ and $5 \% \mathrm{CO}_{2}$. After that, we centrifuged the tubes at $300 \mathrm{x}$ g for 5 minutes, and then the cells were re-suspended in PBS and centrifuged again, thus applying a double wash. The data were analysed using a FACS Calibur flow cytometer with settings as follows: $623 \mathrm{~V}$ for FL1, $505 \mathrm{~V}$ for FL2, 10,000 events and $488 \mathrm{~nm}$ laser. Data were processed using FlowJo 7.6.1 software. Meanwhile, the same protocol was applied for untreated fibroblasts. The experiment was replicated 6 times and the results were expressed as the average of these 6 determinations. Statistical data were analysed using One Way ANOVA method (completed with Student-Newman-Keuls method). Results were considered statistically significant for a $\mathrm{p}$ value $<0.05$ and were expressed as mean \pm S.E.M. (standard error media).

\section{Results and Discussion}

Added with $\mathrm{CoCl}_{2}$, calcein-AM appears to be a good technique for MPT channel opening, following $\mathrm{Ca}^{2+}$ concentration variations in the cell cytoplasm or mitochondria. By increasing $\mathrm{Ca}^{2+}$ concentration, we have induced the MTP opening by ionophore A23187 administration (calcium ionophore).

The ER stress involved in apoptosis of normal gingival fibroblasts and those treated with CsA, nifedipine and phenytoin was observed using thapsigargin (THP), cyclopiazonic acid (ACP), brefeldin A (BFA) and capsaicin as inducers of apoptosis (Figure 1).

In CsA pre-treatment cells, cyclopiazonic acid, capsaicin and thapsigargin caused the reduction of calcein, suggesting mitochondrial permeability transition pore opening due to ER stress (statistically significant $-\mathrm{p}<$ 0.05) (Figure 2).

In our study, cyclopiazonic acid, thapsigargin, brefeldin A and capsaicin also induced significant reduction of mitochondrial calcein loading in fibroblasts treated with nifedipine in culture medium (statistically significant $\mathrm{p}<0.05)$ (Figure 3).

In the phenytoin treated cells, only cyclopiazonic acid and capsaicin induced significant effects $(\mathrm{p}<0.05)$ on the opening of mitochondrial permeability transition pore and this can be seen in the images below (Figure 4).

The opening of the mitochondrial permeability transition pore was highlighted by the reduction of the calcein acetoxymethyl ester fluorescence in the presence of cobalt chloride. This sequence represents an initial stage in the development of apoptosis.
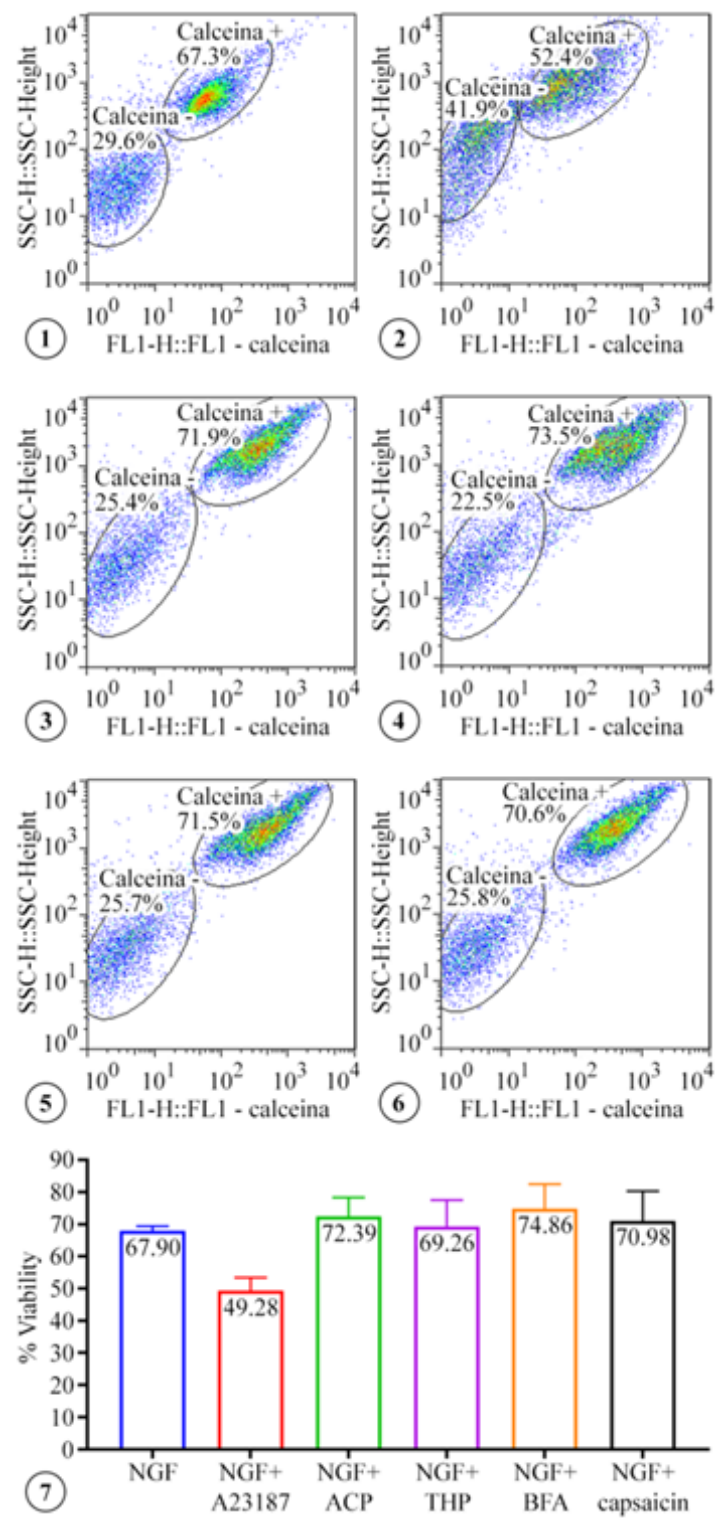

Figure 1.

FACS distribution and statistical analysis (7) for normal gingival fibroblasts (NGF) loaded with calcein (1), under ionophore A23187 (2), ACP (3), THP (4), BFA (5) and capsaicin (6) for $24 \mathrm{~h}$ (data are expressed as a percentage of viable cells from the total number of cells studied, representing 100\%) 
FARMACIA, 2021, Vol. 69, 6
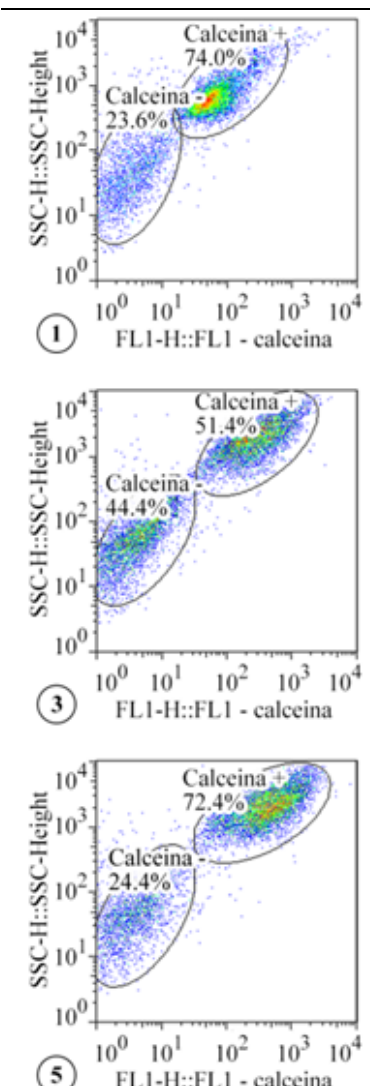

FLI-H::FLI - calceina
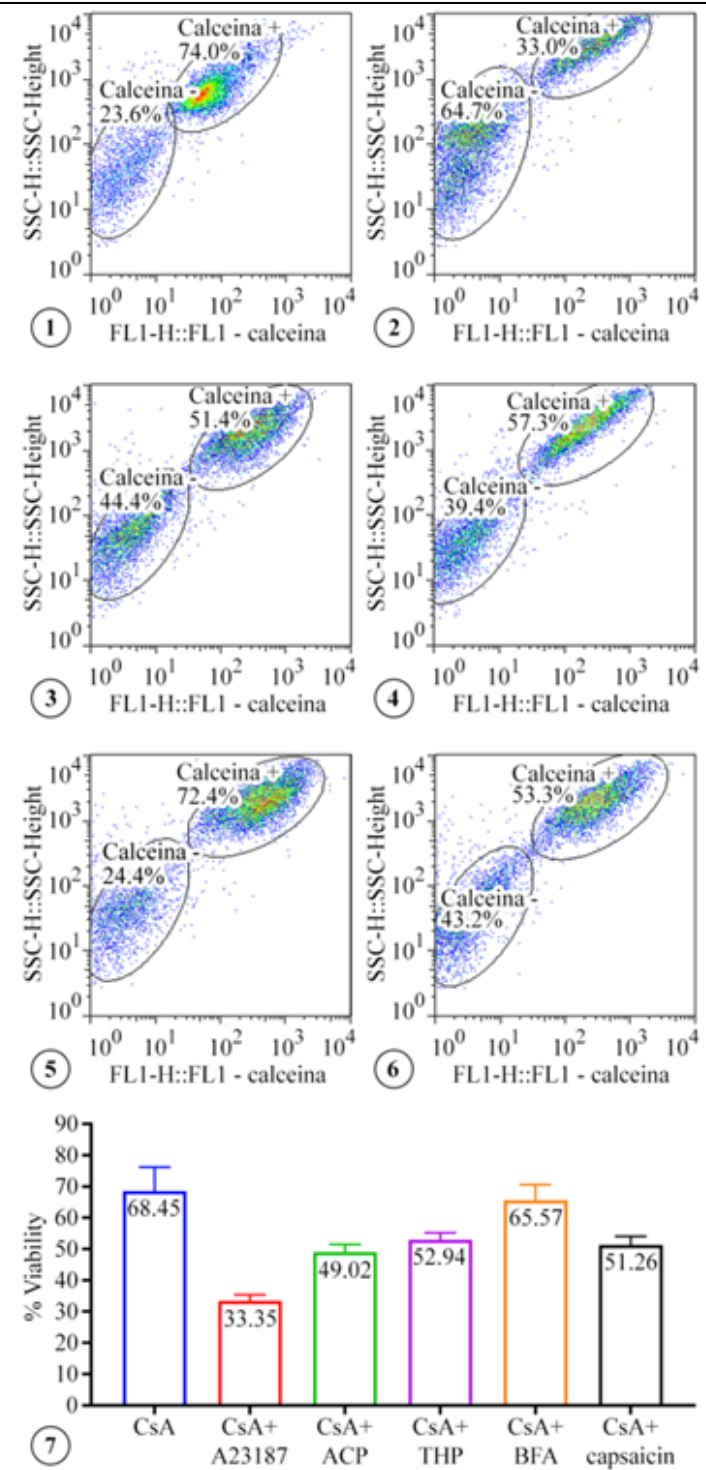

Figure 2.

FACS distribution and statistical analysis (7) for gingival fibroblasts treated with CsA loaded with calcein (1), under ionophore A23187 (2), ACP (3), THP (4), BFA(5) and capsaicin (6) for $24 \mathrm{~h}$ (data are expressed as a percentage of viable cells from the total number of cells studied, representing 100\%)

Induction of endoplasmic reticulum stress in normal fibroblasts using cyclopiazonic acid, tapsigargin, brefeldin A and capsaicin had no statistically significant effects on opening of mitochondrial permeability transition pore. In contrast, in the case of cells previously treated with CsA, nifedipine and phenytoin, the induction of endoplasmic reticulum stress by using inducers caused the opening of the mitochondrial permeability transition pore, meaning apoptosis initiation. Thus, our results showed that there is an obvious link between endoplasmic reticulum stress and the onset of apoptosis in fibroblasts treated with CsA, nifedipine and phenytoin, but not in normal ones.
These results emphasize an increased sensitivity of the endoplasmic reticulum in the case of gingival fibroblasts treated with CsA, nifedipine and phenytoin. Three drugs (phenytoin, nifedipine, and cyclosporine) induce gingival overgrowth and authors like Uzel et al. have suggested differences like these overgrowths. According to Uzel et al., phenytoin-induced overgrowth is more fibrotic than the other two and cyclosporine induced overgrowth is more vascular [24].
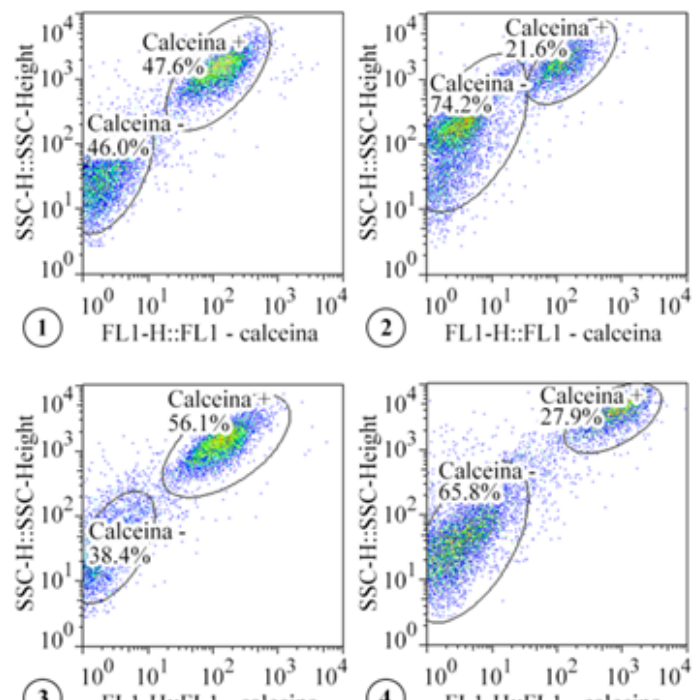

(3) FL1-H::FL1 - calceina
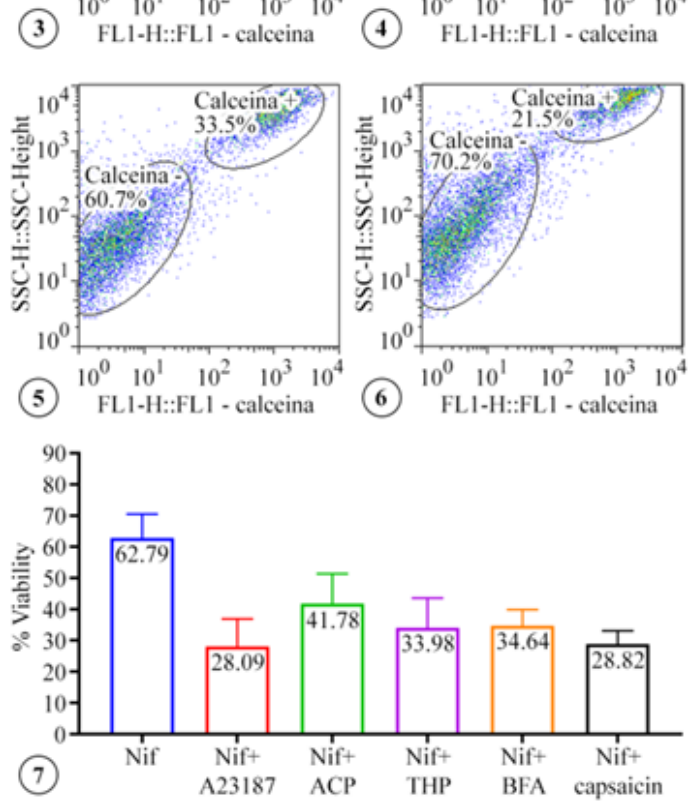

Figure 3.

FACS distribution and statistical analysis (7) for gingival fibroblasts treated with nifedipine loaded with calcein (1), under ionophore A23187 (2), ACP (3), THP (4), BFA (5) and capsaicin (6) for $24 \mathrm{~h}$ (data are expressed as a percentage of viable cells from the total number of cells studied, representing 100\%)

ER and mitochondria play key roles in sensing and reacting to cellular stress. Mitochondrial $\mathrm{Ca}^{2+}$ overload is one of the pro-apoptotic ways leading to the release of mitochondrial apoptotic factors, such as cytochrome c, apoptosis inducing factor (AIF), procaspase-9, Smac/ 
FARMACIA, 2021, Vol. 69, 6

DIABLO, endonuclease $\mathrm{G}$ into the cytosol. ER stress is considered a proapoptotic factor that may cause mitochondrial permeability transition pore opening and apoptosis initiation.
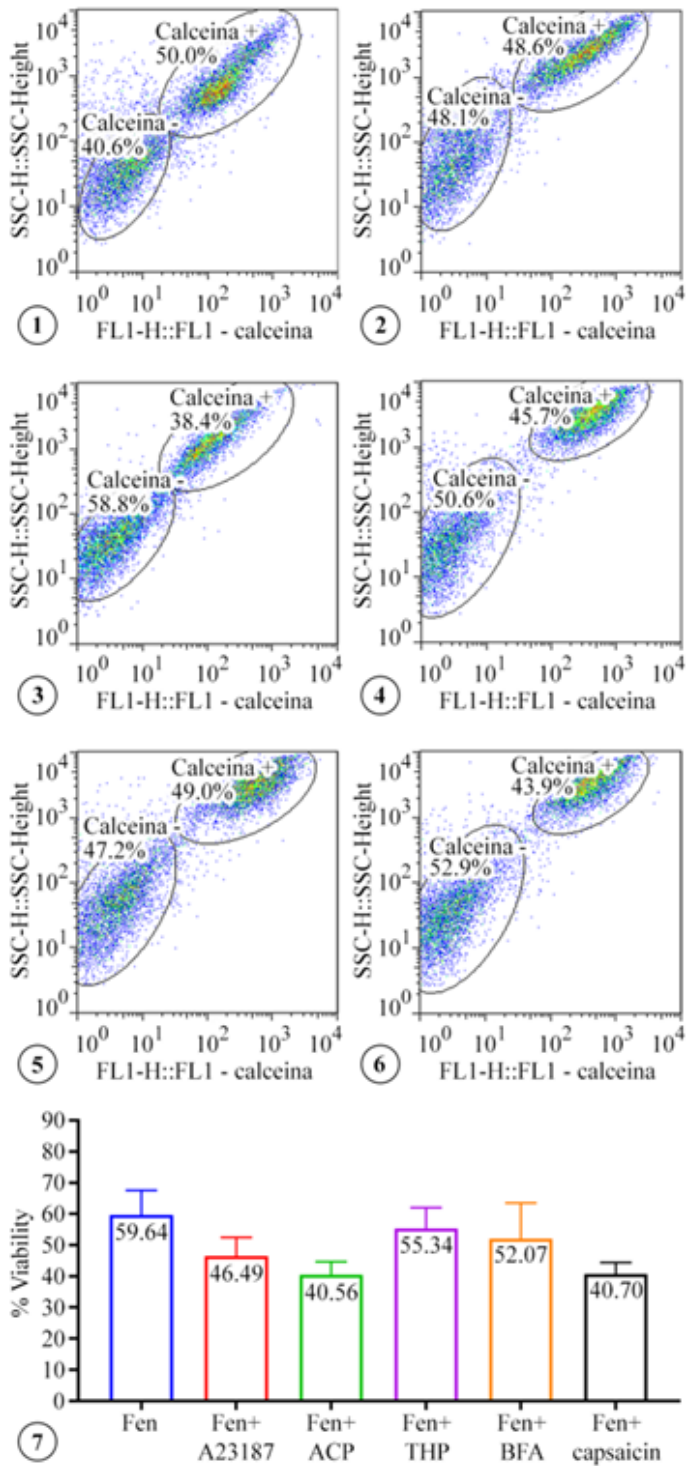

Figure 4.

FACS distribution and statistical analysis (7) for gingival fibroblasts treated with phenytoin loaded with calcein (1), under ionophore A23187 (2), ACP (3), THP (4), BFA (5) and capsaicin (6) for $24 \mathrm{~h}$ (data are expressed as a percentage of viable cells from the total number of cells studied, representing 100\%)

Since ER stress and the unfolded protein response accompanying it can lead to cell death, it is not surprising that these conditions lead to a misfolding protein increase or a decrease in cell capacity to treat these proteins in ER. This can cause cellular dysfunction and even the onset of a disease [13]. Such diseases may be the result of the cells' decreased ability to fold secreted membrane proteins, or a low ability to recognize or respond to misfolded protein and/or increased secretion of abnormally folded proteins [25].
To gain more insight into apoptosis and gingival overgrowth mechanisms, the ER stressor thapsigargin, brefeldin A, capsaicin and cyclopiazonic acid represent valuable experimental tools. Thapsigargin induces apoptosis via the unfolded protein response (UPR) and initiates death receptor 5 and caspase-8-dependent cell death in various cell types. Thapsigargin inhibits ERassociated $\mathrm{Ca}^{2+}$-ATPase and disrupts $\mathrm{Ca}^{2+}$ homeostasis [26].

Brefeldin A is an inhibitor of intracellular protein transport that leads to the accumulation of proteins in the endoplasmic reticulum. It is an inducer of ER stress-mediated apoptosis via the mitochondria-cell death pathway. Brefeldin A can cause changes in the mitochondrial membrane permeability that may lead to cytochrome $\mathrm{c}$ and activation of caspases 3 and 9 [27].

The induction of ER stress in normal fibroblasts using cyclopiazonic acid, thapsigargin, brefeldin $\mathrm{A}$ and capsaicin had no statistically significant effects on mitochondrial permeability pore opening $(\mathrm{p}=1,000)$. These results appear to be similar to those in the literature showing that ER stress inducing substances initiate apoptosis particularly in tumour transformed cells rather than normal cells [28].

Previous studies on capsaicin apoptosis induction have shown that treatment with this compound extracted from hot chili pepper (capsaicin) causes ER stress and calpain activation. In their study, Mi-Ja Lee et al. demonstrated that the mechanism is complex and it involves a rise in intracellular $\mathrm{Ca}^{2+}$, calpain activation, and subsequent mitochondrial membrane depolarization, followed by the mitochondrial release of cytochrome $\mathrm{c}$ and consequent activation of caspase-9 and -7 [29]. Other studies have shown that cyclosporine induces ER stress in gingival fibroblasts through attenuating apoptosis by interfering with permeability transition pore and decreasing calpain expression [28].

Thapsigargin, an inhibitor of $\mathrm{Ca}^{2+}$ - ATPase in endoplasmic reticulum, produces intracellular $\mathrm{Ca}^{2+}$ increases in human hepatoma cell line as $\mathrm{Gu} \mathrm{J}$ et al. have shown in a previous study [30].

In our study, mitochondrial permeability transition pore opening under $\mathrm{Ca}^{2+}$ overload was observed using ionophore A23187 both in normal fibroblasts and especially in those treated with CsA, nifedipine and phenytoin in culture medium.

Being a common denominator among all cell types, the ER governs mechanisms to ensure cell survival, integrity and function [31].

Our study demonstrates a direct link between ER stress and mitochondrial permeability transition pore opening in fibroblasts obtained from drug-induced gingival overgrowth. Inductors for ER stress have no effect on normal fibroblasts. These data suggest a significant involvement of the endoplasmic reticulum in gingival overgrowth induced by CsA, nifedipine and phenytoin. 


\section{Conclusions}

We can conclude that, despite the persistent uncertainty and debates regarding the mechanisms of drug-induced gingival overgrowth, a special role is assigned to the ER stress and its connection with the mitochondrial permeability transition pore. Decoding these mechanisms may provide extremely important pieces of information regarding critical pathways for cell survival and apoptosis, being an important target for future development of new therapeutic agents with minimal periodontal side effects as well.

\section{Conflict of interest}

The authors declare no conflict of interest.

\section{References}

1. Balch WE, Morimoto RI, Dillin A, Kelly JW, Adapting proteostasis for disease intervention. Science, 2008; 319(5865): 916-919.

2. Bharti V, Bansal C, Drug-induced gingival overgrowth: The nemesis of gingiva unraveled. J Indian Soc Periodontol., 2013; 17(2): 182-187.

3. Pisoschi C, Stănciulescu C, Munteanu C, Fusaru AM, Baniță M, Evidence for the epithelial-mesenchymal transition as a pathogenic mechanism of phenytoininduced gingival overgrowth. Farmacia, 2012; 60(2): 168-176.

4. Breckenridge DG, Germain M, Mathai JP, Nguyen M, Shore GC, Regulation of apoptosis by endoplasmic reticulum pathways. Oncogene, 2003; 22(53): 86088618.

5. Baniță M, Pisoschi C, Stănciulescu C, Mercuț V, Scrieciu M, Hâncu M, Crăițoiu M, Phenytoin-induced gingival overgrowth - an immunohistochemical study of tgf- $\beta 1$ mediated pathogenic pathways. Farmacia, 2011; 59(1): 24-33.

6. Goriuc A, Foia GL, Minea B, Luchian AI, Surdu AE, Toma V, Costuleanu M, Mârțu I, Drug-induced gingival hyperplasia - experimental model. Rom J Morphol Embryol., 2017; 58(4): 1371-1376.

7. Ponnaiyan D, Jegadeesan V, Cyclosporine A: Novel concepts in its role in drug-induced gingival overgrowth. Dent Res J (Isfahan), 2015; 12(6): 499-506.

8. Grechin C, Solovăstru LG, Vâță D, Pătrașcu AI, Grăjdeanu AI, Porumb-Andrese E. Inflammatory marker alteration in response to systemic therapies in psoriasis. Exp Ther Med., 2020; 20(1): 42-46.

9. Gu J, Liu H, Fu T, Xu Y, Thapsigargin increases apoptotic cell death in human hepatoma BEL-7404 cells. Cell Res., 1995; 5: 59-65.

10. Kantarci A, Augustin P, Firatli E, Sheff MC, Hasturk $\mathrm{H}$, Graves DT, Trackman PC, Apoptosis in gingival overgrowth tissues. J Dent Res., 2007; 86(9): 888-892.

11. Gherman A, Cainap C, Vesa ŞC, Havasi AD, Trifon A, Cainap SS, Crișan O, Irimie A, Efficacy of cetuximab/panitumumab after previous bevacizumab in metastatic colorectal cancer. Farmacia, 2020; 68(4): 656-664.

12. Lee AS, Kim YJ, Lee CS, Brefeldin a induces apoptosis by activating the mitochondrial and death receptor pathways and inhibits focal adhesion kinase- mediated cell invasion. Basic Clin Pharmacol Toxicol., 2013; 113(5): 329-338.

13. Lee MJ, Kee KH, Suh $\mathrm{CH}$, Lim SC, Oh SH, Capsaicin-induced apoptosis is regulated by endoplasmic reticulum stress- and calpain-mediated mitochondrial cell death pathways. Toxicology, 2009; 264(3): 205214.

14. Lin JH, Walter P, Benedict Yen TS, Endoplasmic reticulum stress in disease pathogenesis. Annu Rev Pathol., 2008; 3: 399-425.

15. Rao RV, Poksay KS, Castro-Obregon S, Schilling B, Row RH, del Rio G, Gibson BW, Ellerby HM, Bredesen DE, Molecular components of a cell death pathway activated by endoplasmic reticulum stress. J Biol Chem., 2004; 279(1): 177-187.

16. Bravo R, Parra V, Gatica D, Rodriguez AE, Torrealba N, Paredes F, Wang ZV, Zorzano A, Hill JA, Jaimovich E, Quest AF, Lavandero S, Endoplasmic reticulum and the unfolded protein response: dynamics and metabolic integration. Int Rev Cell Mol Biol., 2013; 301: 215-290.

17. Lindner P, Christensen SB, Nissen P, Møller VJ, Engedal N, Cell death induced by the ER stressor thapsigargin involves death receptor 5, a non-autophagic function of MAP1LC3B, and distinct contributions from unfolded protein response components. J Cell Commun Signal., 2020; 18(1): 12: 1-23.

18. Manalo RVM, Medina PMB, The endoplasmic reticulum stress response in disease pathogenesis and pathophysiology. Egypt J Med Hum Genet., 2018; 19(2): 59-68

19. Tabas I, Ron D, Integrating the mechanisms of apoptosis induced by endoplasmic reticulum stress. Nat Cell Biol., 2011; 13(3): 184-190.

20. Ozcan L, Ergin AS, Lu A, Chung J, Sarkar S, Nie D, Myers MG Jr, Ozcan U, Endoplasmic reticulum stress plays a central role in development of leptin resistance. Cell Metab., 2009; 9(1): 35-51.

21. Cotrim P, Martelli-Junior H, Graner E, Sauk JJ, Coletta $\mathrm{RD}$, Cyclosporin A induces proliferation in human gingival fibroblasts via induction of transforming growth factor-beta1. J Periodontol., 2003; 74(11): 1625-1633.

22. Bullon P, Gallardo I, Goteri G, Rubini C, Battino M, Ribas J, Newman HN, Nifedipine and cyclosporin affect fibroblast calcium and gingiva. $J$ Dent Res., 2007; 86(4): 357-362.

23. Takeuchi R, Matsumoto H, Arikawa K, Taguchi C, Nakayama R, Nasu I, Hiratsuka K, Phenytoin-induced gingival overgrowth caused by death receptor pathway malfunction. Oral Dis., 2017; 23(5): 653-659.

24. Uzel MI, Kantarci A, Hong HH, Uygur C, Sheff MC, Firatli E, Trackman PC, Connective tissue growth factor in drug-induced gingival overgrowth. J Periodontol., 2001; 72(7): 921-931.

25. Rao SR, Ajitkumar S, Subbarayan R, Girija DM, Cyclosporine-A induces endoplasmic reticulum stress in human gingival fibroblasts - An in vitro study. $J$ Oral Biol Craniofac Res., 2018; 8(3): 165-167.

26. Rao SR, Subbarayan R, Ajitkumar S, Girija DM, 4PBA strongly attenuates endoplasmic reticulum stress, fibrosis and mitochondrial apoptosis markers in cyclosporine treated human gingival fibroblasts. $J$ Cell Physiol., 2018; 233(1): 60-66.

27. Moon JL, Kim YS, Shin WS, Park JW, Regulation of brefeldin A-induced ER stress and apoptosis by 
mitochondrial $\mathrm{NADP}^{+}$-dependent isocitrate dehydrogenase. Biochem Biophys Res Commun., 2012; 417(2): 760-764.

28. Rao SR, Sundararajan H, Subbarayan R, Girija DM, Cyclosporine-A induces endoplasmic reticulum stress and influences pro-apoptotic factors in human gingival fibroblasts. Mol Cell Biochem., 2017; 429(1-2): 179185.

29. Lee MJ, Kee KH, Suh CH, Lim SC, Oh SH, Capsaicin-induced apoptosis is regulated by endoplasmic reticulum stress- and calpain-mediated mitochondrial cell death pathways. Toxicology, 2009; 264(3): 205214.

30. Jun G, Liu H, Fu T, Xu Y, Thapsigargin increases apoptotic cell death in human hepatoma BEL-7404 cells. Cell Res., 1995; 5: 59-65.

31. Yang Y, Sun M, Shan Y, Zheng X, Ma H, Ma W, Wang Z, Pei X, Wang Y, Endoplasmic reticulum stress-mediated apoptotic pathway is involved in corpus luteum regression in rats. Reprod Sci., 2015; 22(5): 572-584. 